\title{
Coupling Effects in Multibeam Reflector Antennas
}

\author{
Schjær-Jacobsen, Hans; Lessow, H.A.; Andersen, J. Bach
}

Published in:

3rd European Microwave Conference

Link to article, DOI:

10.1109/EUMA.1973.331800

Publication date:

1973

Document Version

Publisher's PDF, also known as Version of record

Link back to DTU Orbit

Citation (APA):

Schjær-Jacobsen, H., Lessow, H. A., \& Andersen, J. B. (1973). Coupling Effects in Multibeam Reflector Antennas. In 3rd European Microwave Conference (Vol. Volume 2, pp. 1-1). IEEE.

https://doi.org/10.1109/EUMA.1973.331800

\section{General rights}

Copyright and moral rights for the publications made accessible in the public portal are retained by the authors and/or other copyright owners and it is a condition of accessing publications that users recognise and abide by the legal requirements associated with these rights.

- Users may download and print one copy of any publication from the public portal for the purpose of private study or research.

- You may not further distribute the material or use it for any profit-making activity or commercial gain

- You may freely distribute the URL identifying the publication in the public portal

If you believe that this document breaches copyright please contact us providing details, and we will remove access to the work immediately and investigate your claim 


\section{COUPLING EFFECTS IN MULTIBEAM}

REFLECTOR ANTENNAS

H. Schjær-Jacobsen, H.A. Lessow, J. Bach Andersen

Laboratory of Electromagnetic Theory

Technical University of Denmark

DK-2800, Lyngby, Denmark

\section{SUMMARY}

New results and conceptual design principles concerning multiple beam reflector antennas in which coupling effects are of major influence on antenna performance are presented.

Special attention is paid to a certain class of feeds consisting of minimum scattering antennas (MSA's). The mutual impedance between two identical MSA's is expressed as an integral over their power patterns including complex angles [1]. For a given element spacing power patterns that minimize mutual coupling may be found. However, the patterns which lead to minimum coupling may not be optimum when the illumination of the reflector is considered. This is accounted for by constraining the efficiency for a given f/D-ratio.

As an example of circularly polarized feed antennas detailed numerical analysis of coupling between arbitrarily oriented crossed dipoles is presented. In evaluating the scattered field from crossed dipoles the feeding network is included since a crossed dipole is never an MSA.

The secondary field pattern is calculated by a two-dimensional Rombergintegration of the complex current distribution on the reflector found by the physical optics approximation and contour plots of gain and polarization loss are discussed. Also the scattered near field in the focal region is calculated in order to evaluate coupling between feed elements due to the presence of the reflector.

Finally examples for coverage of specific areas on earth from a synchronous orbit satellite are presented.

[1] W. Wasylkiwskyj and W.K. Kahn, "Theory of mutual coupling among minimum-scattering antennas", IEEE Trans. AP-18, March 1970, pp. 204-215.

This work has been supported by ESTEC/Contract No. 1698/72 AA. 